\title{
Progranulin inhibits LPS-induced macrophage M1 polarization via NF-kB and MAPK pathways
}

Lianlian Liu' ${ }^{1,2,3}$, Hongmei Guo ${ }^{1}$, Aimei Song ${ }^{1,2,3}$, Jiahui Huang ${ }^{1}$, Yu Zhang ${ }^{1}$, Shanshan Jin ${ }^{1}$, Shutong Li ${ }^{1}$, Liguo Zhang ${ }^{1}$, Chengzhe Yang ${ }^{4^{*}+}$ and Pishan Yang ${ }^{1,2,3^{*}+}$

\begin{abstract}
Background: Macrophage M1 polarization plays a pivotal role in inflammatory diseases. Progranulin (PGRN) has potential anti-inflammation action, however, the effect of PGRN on macrophage M1 polarization has been poorly studied. Our study aimed to investigate the effect of PGRN on lipopolysaccharide (LPS)-induced macrophage M1 polarization and clarify the underlying mechanisms.
\end{abstract}

Methods: RAW264.7 cells were polarized to M1 macrophage by LPS with or without recombinant PGRN (rPGRN) and tumor necrosis factor alpha antibody (anti-TNF-a). A cell counting kit-8 assay (CCK-8), flow cytometry, Quantitative Real-Time PCR assay (q-PCR), Western blot assay and enzyme-linked immunosorbent assay (ELISA) were used to determine the effect of different treatments on cell proliferation, expression of surface phenotype marker and expressions and secretion of inflammatory cytokines. The activation of NF-KB/mitogen-activated protein kinase (MAPK) pathways and the nuclear translocation of NF-KB p65 were detected by Western blot and immunofluorescence respectively. THP-1 and primary bone marrow-derived monocytes (BMDMs) were also used to demonstrate effect of PGRN on expressions and secretion of inflammatory cytokines induced by LPS.

Results: In RAW264.7 cells, rPGRN at concentrations below $80 \mathrm{ng} / \mathrm{ml}$ significantly promoted cell proliferation in dose dependent fashion. rPGRN significantly inhibited LPS-induced change of phenotype (CD86/CD206 ratio) and function (tumor necrosis factor (TNF-a) and inducible nitric oxide synthase (iNOS) expressions). LPS-stimulated secretion of TNF- $\alpha$ and activated phosphorylation of IKKa/ $\beta$, IKBa, p65, JNK and p38 and the nucleus translocation of NF-kB p65 were also significantly downregulated by rPGRN. In addition, recombinant TNF-a (rTNF-a) significantly boosted TNF-a and iNOS expression vs the control group. Moreover, anti-TNF-a significantly inhibited LPS-induced TNF-a and iNOS expression. In THP-1 and BMDM cells, reversing effect of rPGRN on LPS-enhanced expressions of TNF- $a$ and iNOS and secretion of TNF-a was further demonstrated.

(Continued on next page)

\footnotetext{
*Correspondence: yangchengzhe19@163.com; yangps@sdu.edu.cn

${ }^{\dagger}$ Chengzhe Yang and Pishan Yang contributed equally to this work.

${ }^{4}$ Department of Oral and Maxillofacial Surgery, Qilu Hospital and Institute of

Stomatology, Shandong University, Jinan 250012, Shandong, People's

Republic of China

'Department of Periodontology, School of Stomatology, Shandong

University, 44 West Wenhua Road, Jinan 250012, Shandong, People's

Republic of China

Full list of author information is available at the end of the article
}

(c) The Author(s). 2020 Open Access This article is licensed under a Creative Commons Attribution 4.0 International License, which permits use, sharing, adaptation, distribution and reproduction in any medium or format, as long as you give appropriate credit to the original author(s) and the source, provide a link to the Creative Commons licence, and indicate if changes were made. The images or other third party material in this article are included in the article's Creative Commons licence, unless indicated otherwise in a credit line to the material. If material is not included in the article's Creative Commons licence and your intended use is not permitted by statutory regulation or exceeds the permitted use, you will need to obtain permission directly from the copyright holder. To view a copy of this licence, visit http://creativecommons.org/licenses/by/4.0/. The Creative Commons Public Domain Dedication waiver (http://creativecommons.org/publicdomain/zero/1.0/) applies to the data made available in this article, unless otherwise stated in a credit line to the data. 
(Continued from previous page)

Conclusions: PGRN down-regulates LPS-induced macrophage M1 polarization in phenotype and function via NFKB/MAPK signaling pathways.

Keywords: PGRN, Macrophage polarization, NF-KB, MAPK, Lipopolysaccharide (LPS)

\section{Background}

Periodontitis is an infectious and inflammatory disease characterized by progressive infiltration of bacteria and inflammatory cytokines into periodontal tissues, resulting in attachment loss, alveolar bone absorption and apical migration of the junctional epithelium [1]. Although some special bacteria initiate periodontal inflammation, the host response motivated by bacterial products, for example, Porphyromonas gingivalis (P.g) LPS, plays an equal important role in mediating periodontal tissue breakdown [2]. Host-derived interleukin-1 (IL-1), IL-6, TNF- $\alpha$, matrix metalloproteinases (MMPs) and prostanoids are main mediators for most of the tissue destruction [3-5].

The monocyte-macrophage plays an important role both in the adaptive immune response and innate immunity [6]. Plenty of evidences show that macrophages derived from circulating mononuclear cells and tissue resident cells exist in the diseased tissues of periodontitis and are leading players in immunoreaction against periodontal pathogens, contributing to the initiation of periodontal inflammation $[7,8]$. The number of macrophages and macrophagessecreted pro-inflammatory cytokines including IL-1, IL-8, TNF- $\alpha$ and so on are elevated in periodontitis-associated gingival tissue biopsies [9]. Macrophages in gingival tissue play a dural role in the host's defense against periodontal pathogen infection and in development of periodontitis depending on their polarization status [10].

When macrophages are recruited to diseased tissues, they are primed into different phenotypes depending on their exposure to different stimuli. When stimulated by LPS or/and interferon gamma (IFN- $\gamma$ ), macrophages differentiate into M1 phenotype, involved in proinflammatory activity and in host defense against bacteria and viruses. On the contrary, IL-4 or/and IL-13 induces macrophages to differentiate into M2 phenotype, behaving anti-inflammatory and pro-healing functions [7]. A variety of studies demonstrate that M1 macrophages predominate in gingival infiltrating macrophages of the mouse periodontitis model via P.g oral infection [11] and in human gingival tissue infected with periodontal disease $[10,12]$. M1 macrophages produce a great mount of TNF- $\alpha$, nitric oxide and IL-12 in response to P.g stimulation [13, 14]. Moreover, increased M1/M2 macrophage ratio augments orthodontic root resorption [15]. Therefore, modulating macrophage polarization status may be an important strategy for periodontal disease therapy [12].
PGRN is known as protein with the molecular mass of about $68.5<\mathrm{kDa}$ [16] which contains seven and one-half copies of granulin repeats [17]. As a multifunctional growth factor [18], PGRN is proved to be associated with tumorigenesis [19], neurodegeneration [20], wound healing [21] and early embryogenesis [22]. In regard of inflammation modulation, PGRN has been shown to promote proliferation of Treg cells and IL-10 secretion, and inhibit neutrophil degranulation, at least partly, through directly binding to TNF receptors (TNFRs) and antagonizing TNF-mediated pro-inflammatory signaling pathway [23, 24]. Additionally, PGRN has been demonstrated to have the protective role in osteoarthritis [23, 25], inflammatory bowel disease [26], psoriasis [27], and various autoimmune diseases [28, 29]. Our previous studies demonstrate that PGRN is highly expressed in periodontitis tissues such as the gingiva and gingival crevicular fluid and recombinant PGRN plays protective role in experimental periodontitis in rats [30] and promotes inflammatory periodontal bone defect regeneration in rats by inhibition of inflammation and osteoclast and promotion of osteogenesis [31]. However, the role of PGRN in modulating macrophage function has been seldom investigated [32]. Therefore, the current study was conducted to investigate the inhibition effect of PGRN on LPS-induced macrophage M1 polarization and the associated signaling pathways to provide a further insight of underling mechanism of PGRN anti-inflammatary activity.

\section{Results \\ Effect of LPS on macrophage M1 polarization and PGRN expression}

After stimulated by $100<\mathrm{ng} / \mathrm{ml}$ LPS or normal medium for $24<\mathrm{h}$, LPS-stimulated RAW264.7 cells showed significantly higher expression of CD86, the special surface phenotype marker of M1, than negative control (Fig. 1a, b). In addition, mRNA and protein expression of iNOS and TNF- $\alpha$, the special functional markers for M1, and secretion of TNF- $\alpha$ also significantly increased (Fig. 1c, $\mathrm{d}, \mathrm{e}, \mathrm{f})$. Interestingly, compared to the control, LPS stimulation for 24 or $48<$ h significantly down-regulated PGRN expression both in gene and protein expression (Fig. 1g, i, j) and its secretion was also significantly decreased after $48<$ h stimulation (Fig. 1h). This suggests that PGRN may be involved in LPS-induced macrophage M1 polarization. 

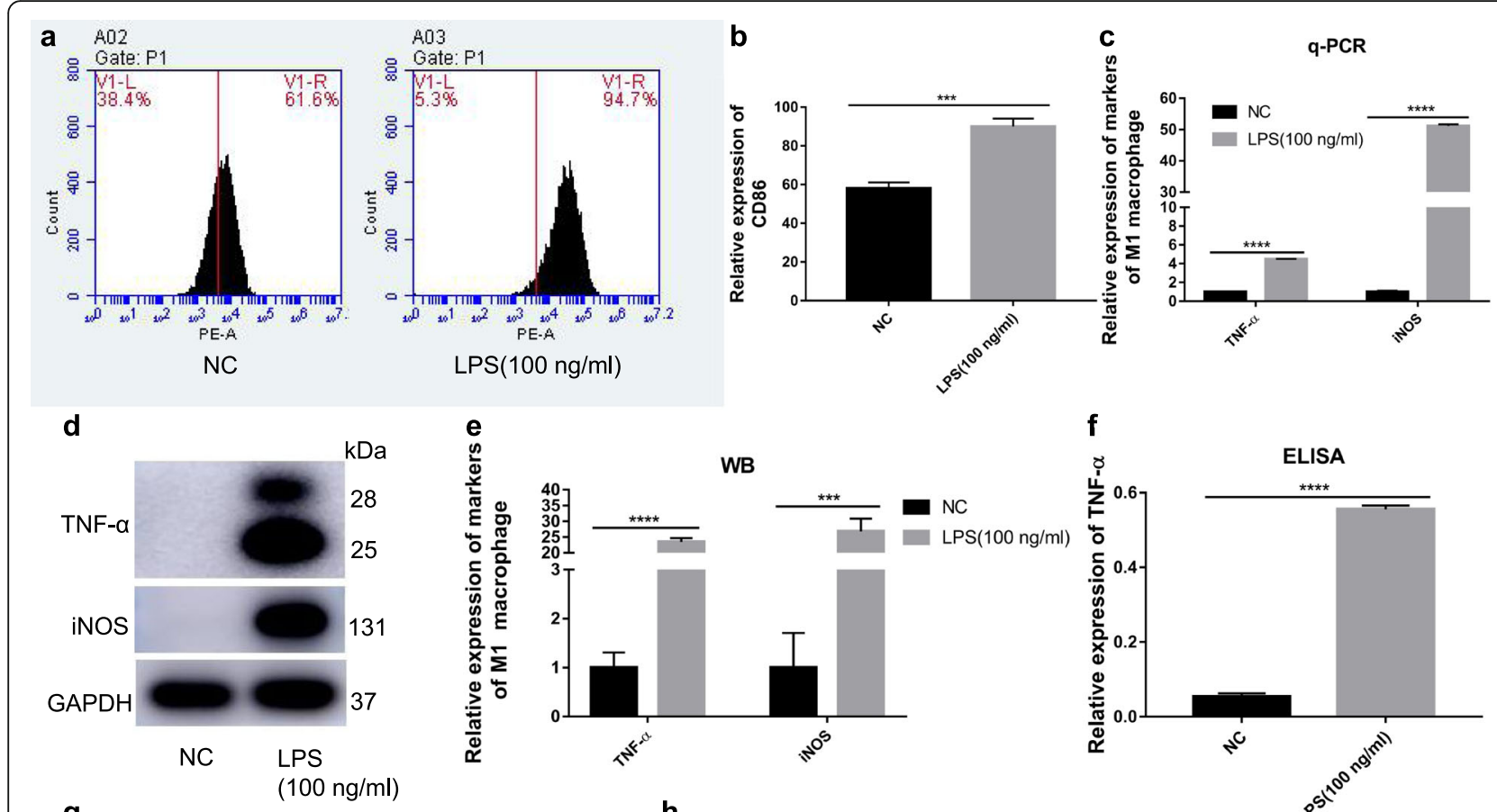

g

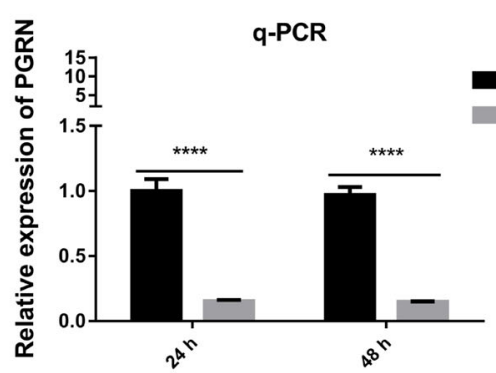

h

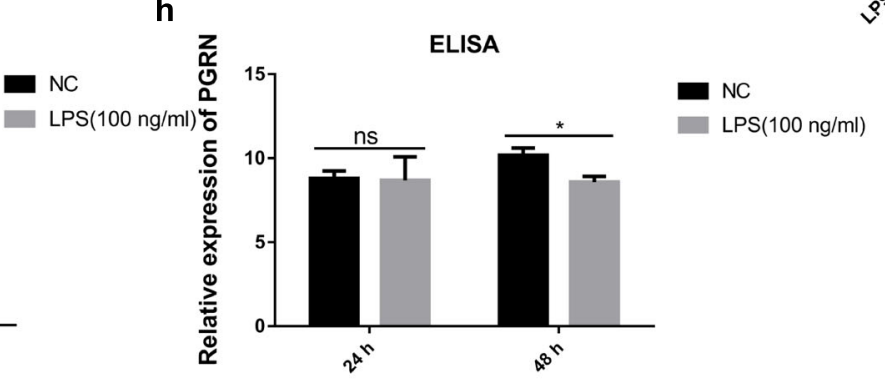

i
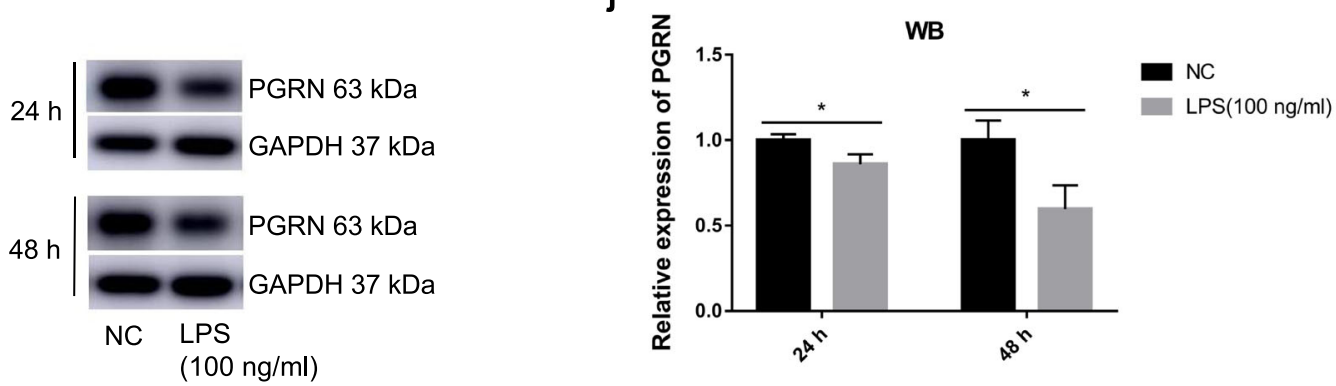

Fig. 1 LPS induces macrophage M1 polarization whereas inhibits PGRN expression Cells were treated with $100 \mathrm{ng} / \mathrm{ml}$ LPS for $24 \mathrm{~h}$ and the normal medium containing equal amount of PBS to LPS groups was used as negative control. $\mathbf{a}, \mathbf{b}$ CD86 expression were detected by flow cytometry. $\mathbf{c}$ The gene level of TNF- $a$ and iNOS were determined with q-PCR. $\mathbf{d}$, e The protein level of TNF-a and iNOS were revealed by western-blot. $\mathbf{f}$ The secretion level of TNF-a was evaluate by ELISA. Cells were treated with $100 \mathrm{ng} / \mathrm{ml} \mathrm{P.g-LPS} \mathrm{for} 24$ and 48 h. $\mathbf{g}$ The gene level of PGRN were detected by $q-P C R$. $\mathbf{h}$ The secretion level of PGRN were evaluated by ELISA. $\mathbf{i}, \mathbf{j}$ The protein level of PGRN were determined by Western blot. $\left.N=3, P<0.05\left(^{*}\right), P<0.001{ }^{(* *}\right)$ or $P<0.00011^{(* * *)}$

Effects of rPGRN on proliferative capacity of RAW264.7 cells

CCK-8 assays revealed that at concentrations below $80<\mathrm{ng} / \mathrm{ml}$, rPGRN significantly promoted cell proliferation in dose dependent fashion after cultured for 24 and $48<\mathrm{h}$ (Fig. 2a, b, d). Nevertheless, proliferative capacity of cells cultured at 160 and 320 $<\mathrm{ng} / \mathrm{ml}$ rPGRN approached to flat, and even declined. Furthermore, the proliferative capacity of RAW264.7 cells treated with different concentrations of rPGRN was descending as processing time increases (Fig. 2a, b, c, d). 
a

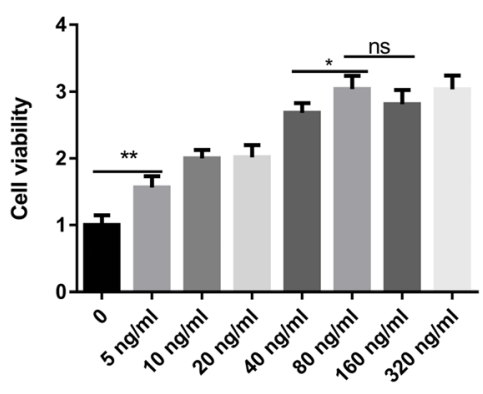

C

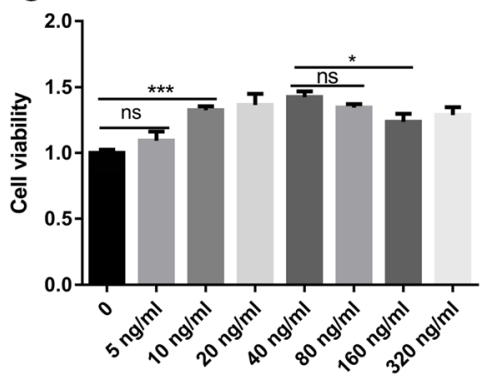

b

$48 \mathrm{~h}$

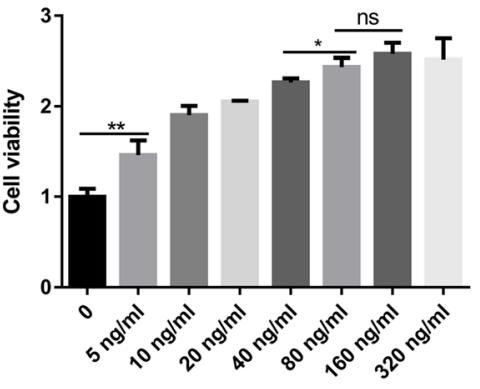

d

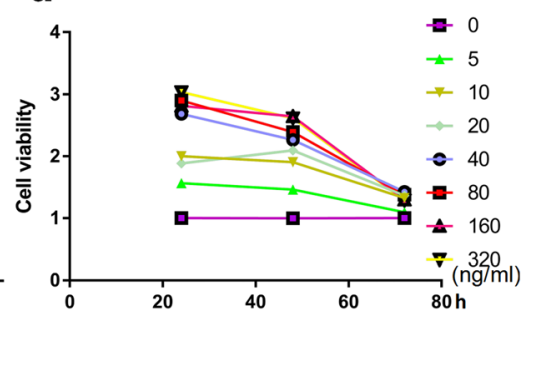

Fig. 2 Effects of PGRN on RAW264.7 viability. a-c The effect of 5, 10,20,40,80,160 and $320 \mathrm{ng} / \mathrm{ml} \mathrm{rPGRN}$ on RAW264.7 cells was detected by

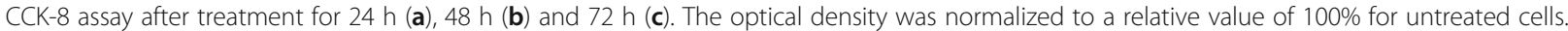
d Cell proliferation curve. $N=3, P<0.05(*), P<0.01\left(^{* *}\right)$ or $P<0.001(* *)$

\section{Effects of rPGRN on LPS-induced M1 polarization in RAW264.7 cells}

RAW264.7 cells were stimulated by LPS plus $0,5,10,20$, 40 and $80<\mathrm{ng} / \mathrm{ml} \mathrm{rPGRN}$ and normal medium containing equal amount of PBS to rPGRN and LPS groups was used as negative control. Their phenotype and function status were characterized by flow cytometry, q-PCR, Western blot and ELISA. The results showed that rPGRN at concentrations of 5,10 and $20<\mathrm{ng} / \mathrm{ml}$ significantly reversed LPS-promoted CD86/CD206 expression ratio, of which 20 $<\mathrm{ng} / \mathrm{ml}$ rPGRN presented most obvious effect (Fig. 3a, b). Similarly, rPGRN significantly reversed LPS-enhanced mRNA of TNF- $\alpha$ and iNOS at concentrations from 5 to $80<\mathrm{ng} / \mathrm{ml}$, among which $10<\mathrm{ng} / \mathrm{ml}$ rPGRN presented most obvious effect (Fig. 3c, d). It also inhibited LPSenhanced protein expression of iNOS (at concentrations from 5 to $40<\mathrm{ng} / \mathrm{ml}$ ) (Fig. 3e, f) and TNF- $\alpha$ (at 5 and $10<$ $\mathrm{ng} / \mathrm{ml}$ ) (Fig. 3e, g), as well as secretion of TNF- $\alpha$ (at 5 and $10 \mathrm{ng} / \mathrm{ml}$ ) (Fig. 3h). This implies that PGRN can inhibit LPS-induced M1 polarization in RAW264.7 cells.

\section{The key role of TNF- $a$ in LPS-induced macrophage M1 polarization}

Previous research has identified that autocrine TNF- $\alpha$ plays a key role in apoptosis in LPS-induced macrophages [33]. It is also reported that PGRN exerts its anti-inflammatary action mainly via binding to TNFR1 to antagonize TNF- $\alpha$ pro-inflammation action [23]. To explore the key role of TNF- $\alpha$ and observe and conjecture whether PGRN antiM1 polarization is related to TNFRs in LPS-induced macrophage M1 polarization, we stimulate RAW264.7 cells by rTNF- $\alpha$, P.g-LPS and P.g-LPS plus anti-TNF- $\alpha$. Results showed that no significant difference in CD86 expression existed between 20 to $40 \mathrm{ng} / \mathrm{ml} \mathrm{rTNF-} \alpha$ and the control groups and anti-TNF- $\alpha$ exerted no significant influence on P.g-LPS promoted CD86 expression (Fig. 4a, b). Nevertheless, $40 \mathrm{ng} / \mathrm{ml} \mathrm{rTNF}-\alpha$ significantly enhanced mRNA and protein expression of TNF- $\alpha$ and iNOS (Fig. 4c-g). More interestingly, anti-TNF- $\alpha$ significantly down-regulated LPSstimulated expression of iNOS and intracellular TNF- $\alpha$ (Fig. 4c-g). This implies that secondary TNF- $\alpha$ expression followed by LPS stimulation plays a crucial role in LPSactivated M1 macrophage functional status.

\section{rPGRN inhibits LPS-activated NF-KB/MAPK pathways}

To clarify the mechanism of PGRN inhibition of LPSinduced M1 polarization in RAW264.7, the change of NF$\kappa \mathrm{B}$ and MAPK signaling molecules was detected by Western blot. As shown in Fig. 5, rPGRN significantly reduced LPS-induced phosphorylation of IKK $\alpha / \beta$ (Fig. 5a-c), ІкB $\alpha$ (Fig. 5d, e), p65 (Fig. 5f, g), JNK (Fig. 5h, i) and p38 (Fig. 5j, k) and NF-кB p65 translocation from the cytoplasm to the nucleus (Fig. 6), though without LPS stimulation it was able of activating the phosphorylation of IKK $\alpha / \beta$ (Fig. $5 \mathrm{a}-\mathrm{C}$ ), JNK 

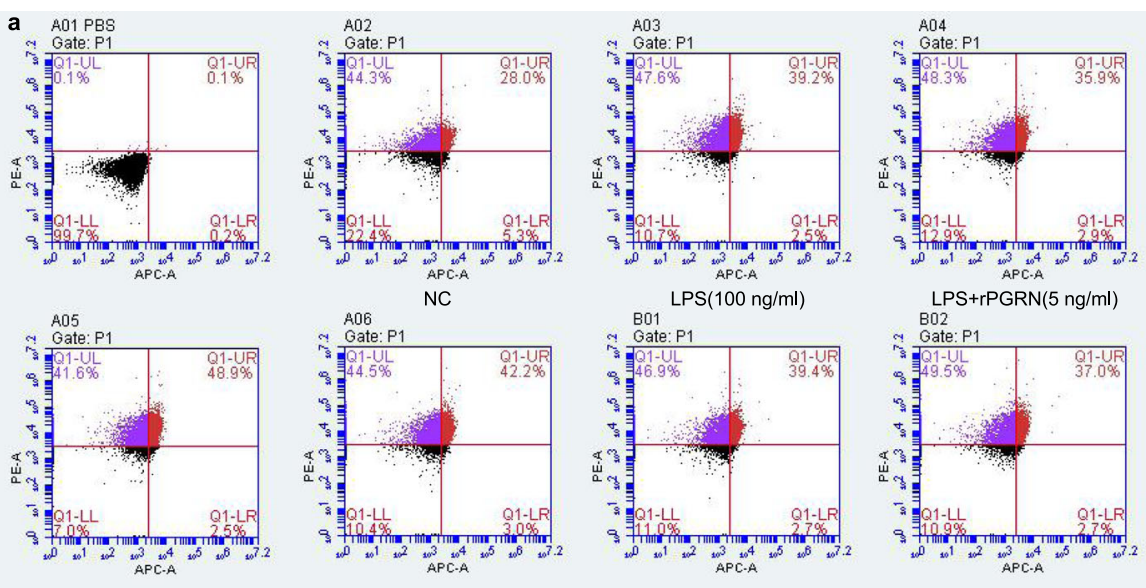

LPS+rPGRN(5 ng/ml)

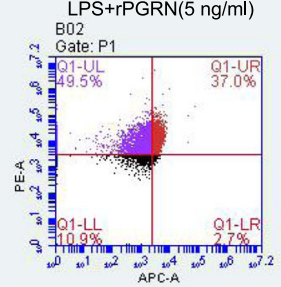

LPS+rPGRN(10 ng/ml)

LPS+rPGRN(20 ng/ml)

LPS+rPGRN(40 ng/ml)

LPS+rPGRN(80 ng/ml)
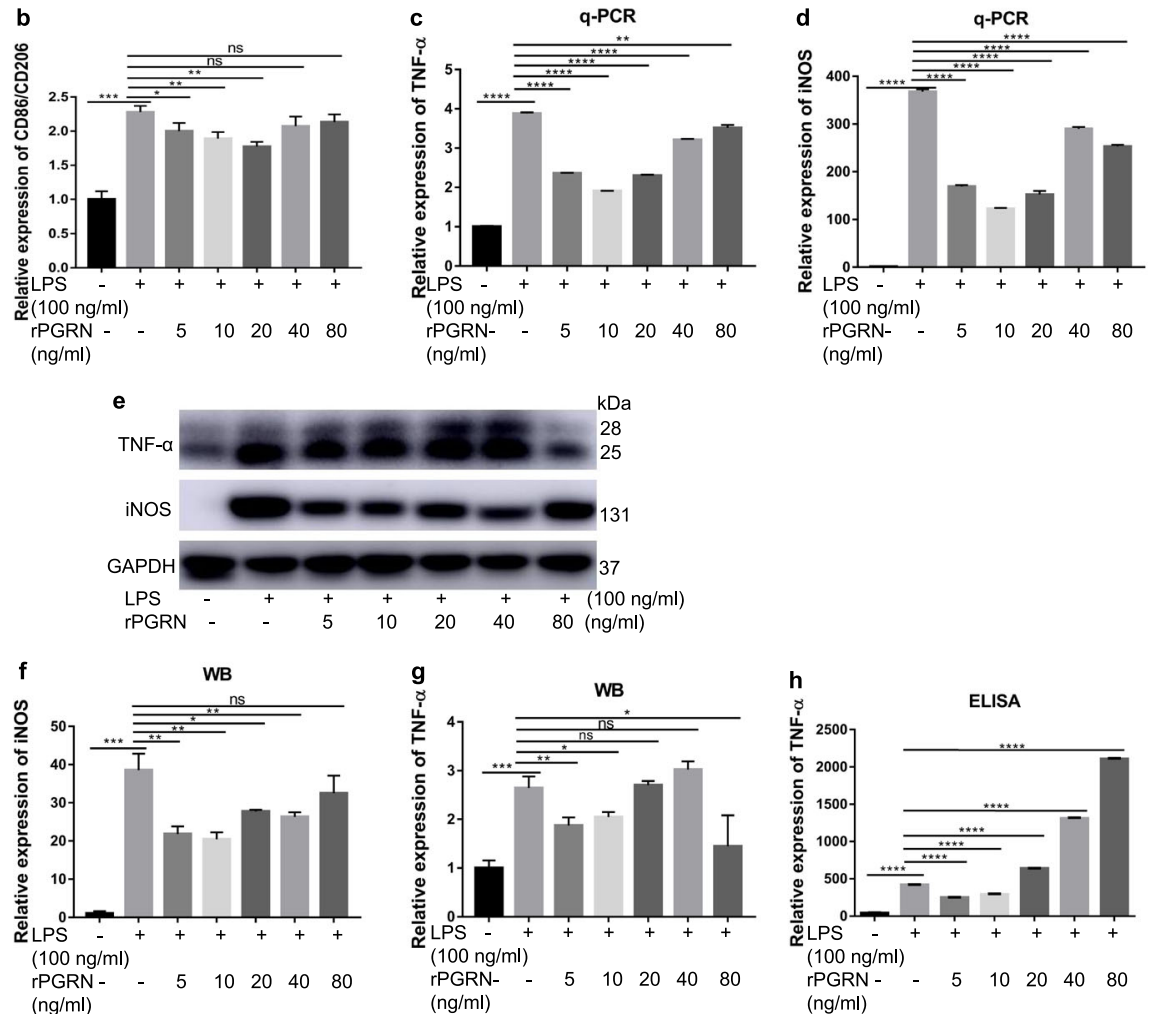

Fig. 3 Inhibitory effects of rPGRN on CD86/CD206 ratio and inflammatory cytokines (TNF-a and iNOS) expression in LPS-stimulate RAW264.7 cells. Cells were treated with LPS plus 5, 10, 20, 40, and $80 \mathrm{ng} / \mathrm{ml}$ rPGRN for $24 \mathrm{~h}$ and normal medium containing equal amount of PBS to rPGRN and LPS groups was used as negative control. a, b CD86/CD206 ratio was detected by flow cytometry. $\mathbf{c}$, d TNF-a (c) and iNOS (d) mRNA expression were determined with q-PCR. e-g TNF-a $(\mathbf{e}, \mathbf{f})$ and $\operatorname{INOS}(\mathbf{e}, \mathbf{g})$ protein expression were revealed by Western blot. $\mathbf{h}$ TNF-a secretion expression were evaluated by ELISA. $N=<3, P<0.05\left(^{(*}\right), P<0.01\left(^{(*}\right), P<0.001\left(^{* * *}\right)$ or $p<0.0001\left(^{(* * *)}\right.$

(Fig. 5h, i) and p38 (Fig. 5j, k) vs negative control group. In addition, rPGRN significantly down-regulated phosphorylation of ERK though LPS had no effect on it (Fig. 5l, m).

\section{rPGRN inhibits LPS-activated macrophage M1 polarization} in BMDMs and THP-1 cells

To further demonstrate above results in RAW.264.7 cells, BMDMs and THP-1 cell line were used to verify the effect of PGRN on functional change induced by LPS. As in RAW264.7 cells, rPGRN at $10 \mathrm{ng} / \mathrm{ml}$ significantly reversed LPS-enhanced mRNA and protein expression of TNF- $\alpha$ and iNOS (Fig. 7a-f) and secretion of TNF- $\alpha$ (Fig. 7g).

\section{Discussion}

Plenty of studies indicate that macrophages, when as M1 phenotype, play a vital role in onset and development of 
a

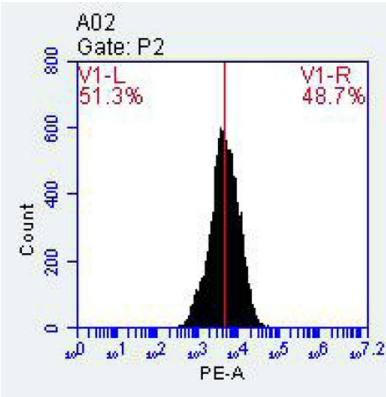

NC

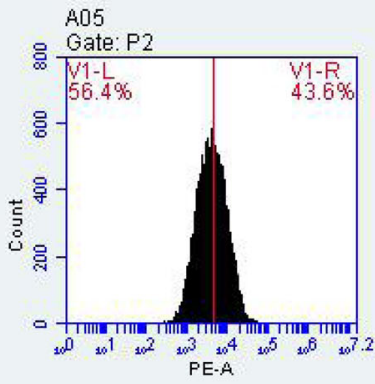

$20 \mathrm{ng} / \mathrm{ml}$ rTNF- $\alpha$

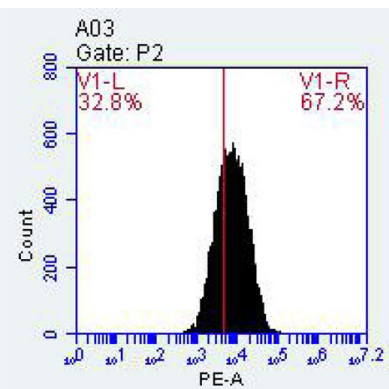

LPS

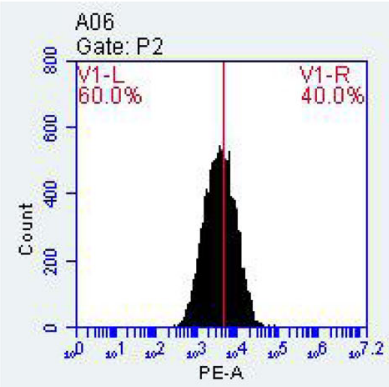

$30 \mathrm{ng} / \mathrm{ml}$ rTNF- $\alpha$

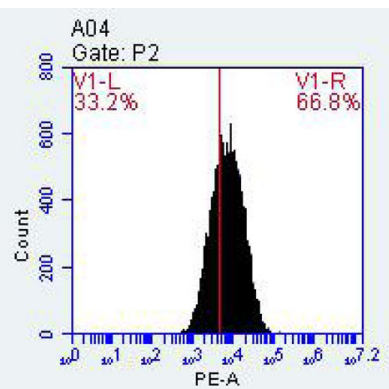

LPS+anti-TNF- $\alpha$

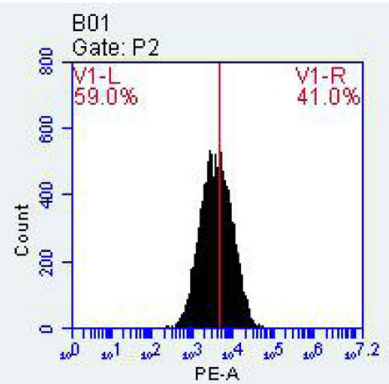

$40 \mathrm{ng} / \mathrm{ml}$ rTNF- $\alpha$

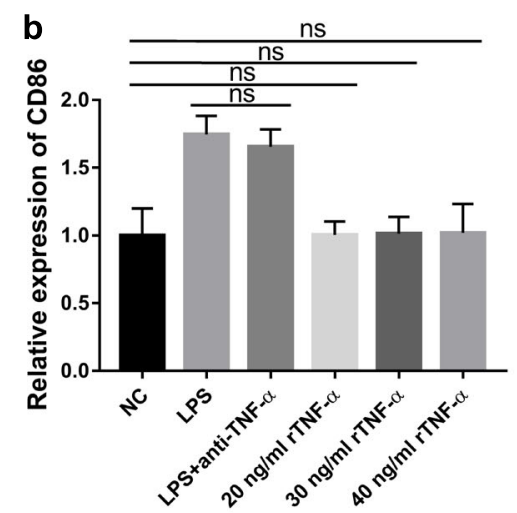

e

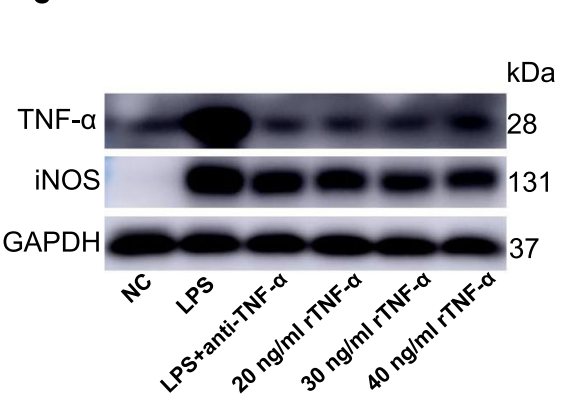

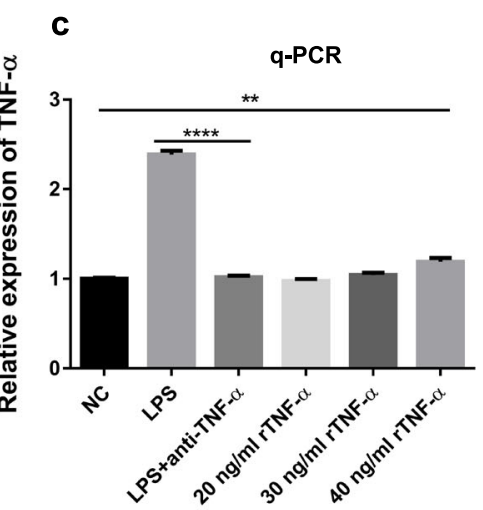

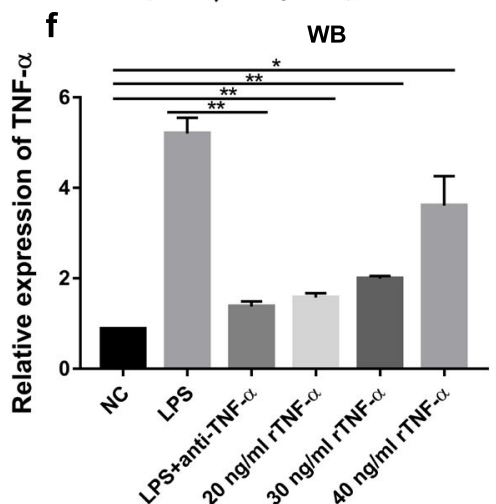

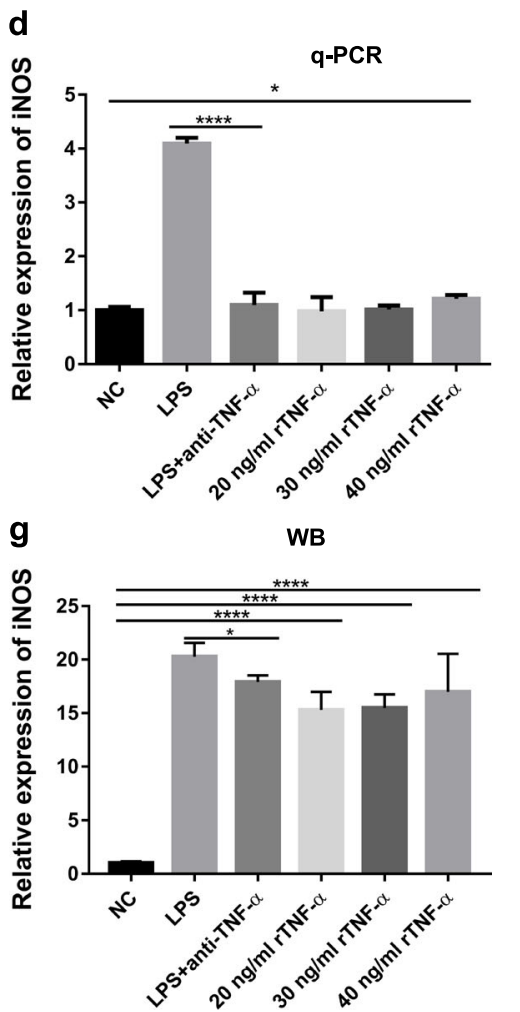

d

Fig. 4 Effect of TNF-a on M1 polarization and of anti-TNF-a on LPS-induced M1 polarization in RAW264.7 cells. Cells were treated with LPS or plus anti-TNF-a or simple rTNF- $a$ at concentration of $20,30,40 \mathrm{ng} / \mathrm{ml}$ for $24 \mathrm{~h}$ and normal medium containing equal amount of PBS to rTNF-a and LPS groups was used as negative control. $\mathbf{a}, \mathbf{b}$ CD86 expression was detected by flow cytometry. $\mathbf{c}$, $\mathbf{d}$ The gene level of TNF-a (c) and iNOS (d) were determined with q-PCR. e- $\mathbf{g}$ The protein level of TNF-a $(\mathbf{e}, \mathbf{f})$ and iNOS $(\mathbf{e}, \mathbf{g})$ were revealed by Western blot. $N=3, P<0.05(*), P<0.01$ $\left(^{* *}\right)$ or $p<0.0001$ (***) $^{* *}$ 


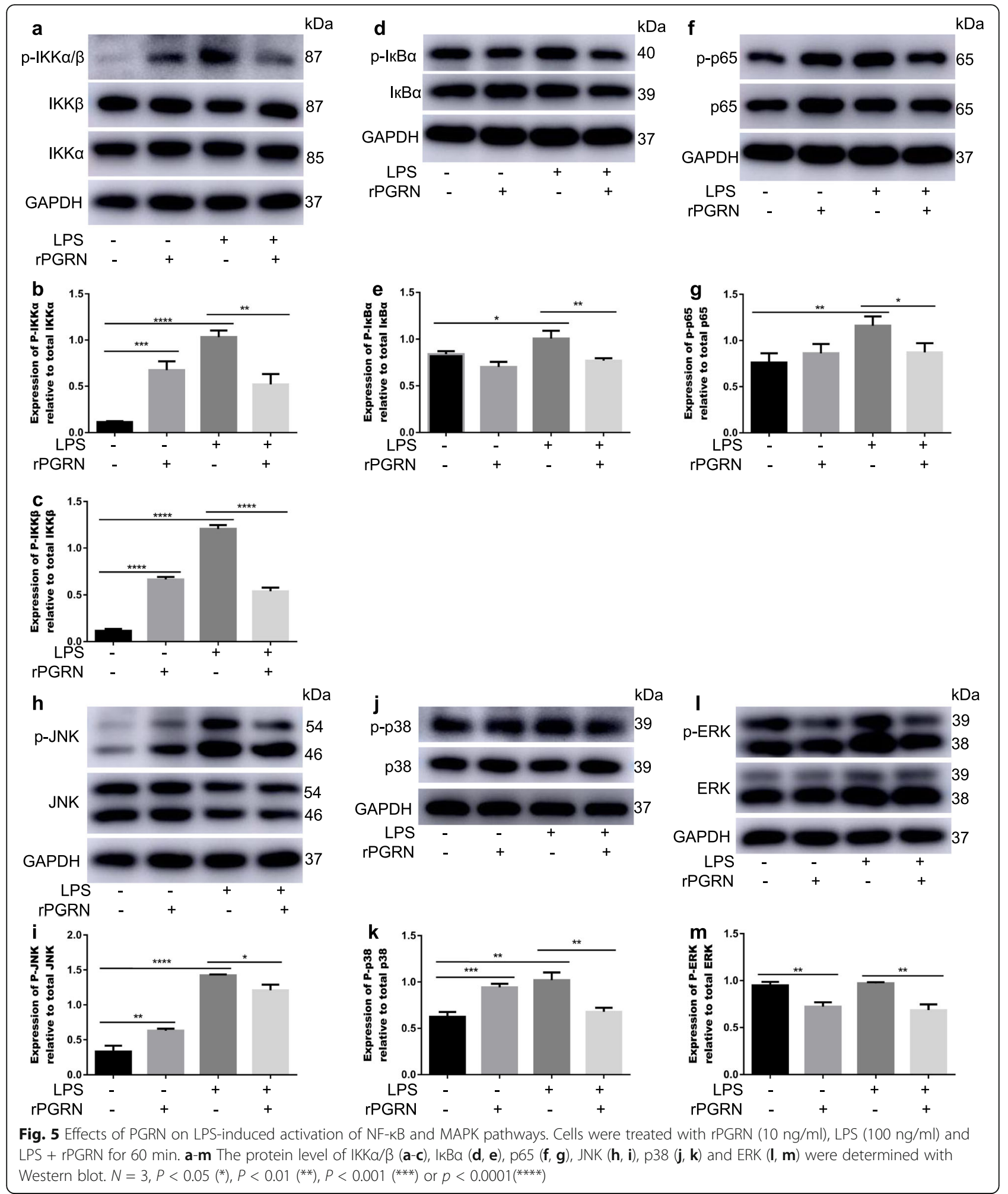

periodontitis [34], while PGRN, identified as an endogenous antagonist of TNF- $\alpha$ by competitively binding to TNFRs, has potential positive action in autoimmune and inflammatory diseases, such as osteoarthritis [35] and periodontitis [30]. In this study, we demonstrated that rPGRN inhibited LPS-induced macrophage M1 polarization and these effects were associated with NFкВ and MAPK pathway inhibition. 


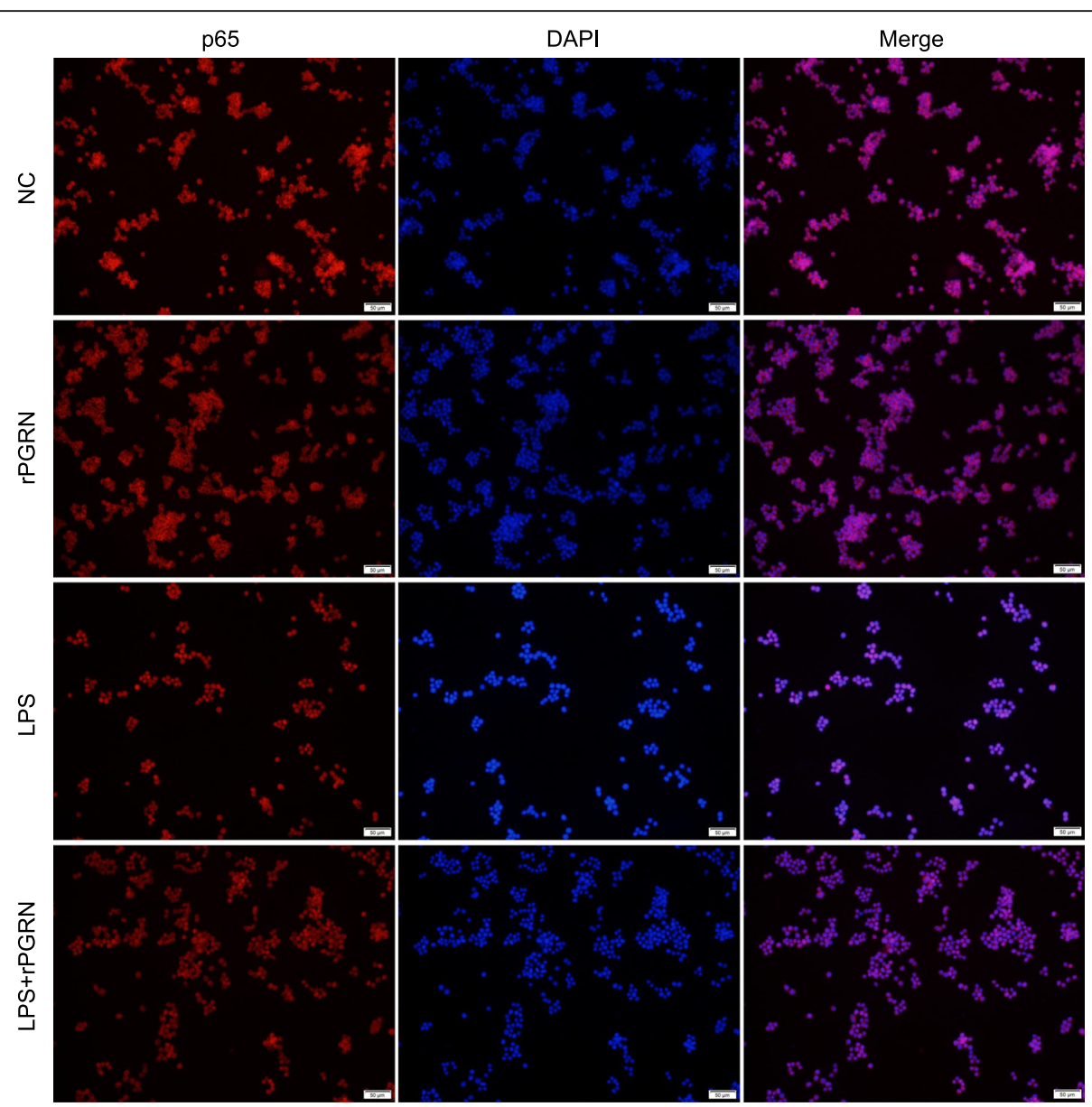

Fig. 6 Effect of PGRN on nuclear translocation of NF-KB p65. Cells treated with rPGRN (10 ng/ml), LPS (100 ng/ml) and LPS + rPGRN for 60 min. The nuclear translocation of NF-KB p65 was evaluated by immunofluorescence staining (NF-KB p65, red fluorescent signals; DAPI, blue signals; magnification: $\times 200$ )

Porphyromonas gingivalis is the main pathogen bacteria of periodontitis and P.g-LPS plays a key role in mediating differentiation and function of M1 macrophages $[13,36,37]$ and in periodontal tissue breakdown [2]. However, other report demonstrate that exposure to P.g-LPS results in diminished pro-inflammatory cytokine production [38]. There is also study showing that there is not significant difference in macrophage polarization between periodontitis and healty tissues [39]. This suggests that, given the importance of macrophages in inflammatory diseases, the effect of P.g-LPS on macrophage polarization needs to be elucidated. The present study, as previously reported [13, 14, 36], validated that macrophages underwent M1 phenotypic and functional changes under P.g-LPS stimulation. Interestingly, with the increase of the expression of M1-specific marker and functional molecules, the expression of endogenous PGRN was significantly reduced, suggesting that PGRN is involved in the regulation of M1 polarization under P.g-LPS stimulation.
It is well documented that CD86 and CD206 are special phenotypic markers of $\mathrm{M} 1$ and $\mathrm{M} 2$ macrophages respectively and iNOS and TNF- $\alpha$ are special functional markers of M1. To further investigate the effect of PGRN on M1 polarization, RAW264.7 cells were stimulated by P.g-LPS with or without rPGRN. We found that rPGRN at range of 5 to $20 \mathrm{ng} / \mathrm{ml}$ suppressed LPS-enhanced CD86/CD206 ratio and the expression of TNF- $\alpha$ and iNOS. This demonstrates that PGRN can reverse macrophage M1 polarization under P.g-LPS stimulation, in consistent with study by Yoo et al., showing that PGRN reduces inflammatory gene expression in palmitate-induced macrophage [40].

It has been reported that PGRN acts via competitively antagonizing TNFRs, while TNF- $\alpha$ was one of the most important marker molecules of M1 macrophages [41]. In order to clarify the role of secondary TNF- $\alpha$ in M1 polarization and to speculate whether PGRN anti-M1 polarization is related to TNFRs, we stimulated RAW264.7 with exogenous TNF- $\alpha$ and found that TNF- $\alpha$ enhanced expression of iNOS and endogenous TNF- $\alpha$, but exerted no influence on special 

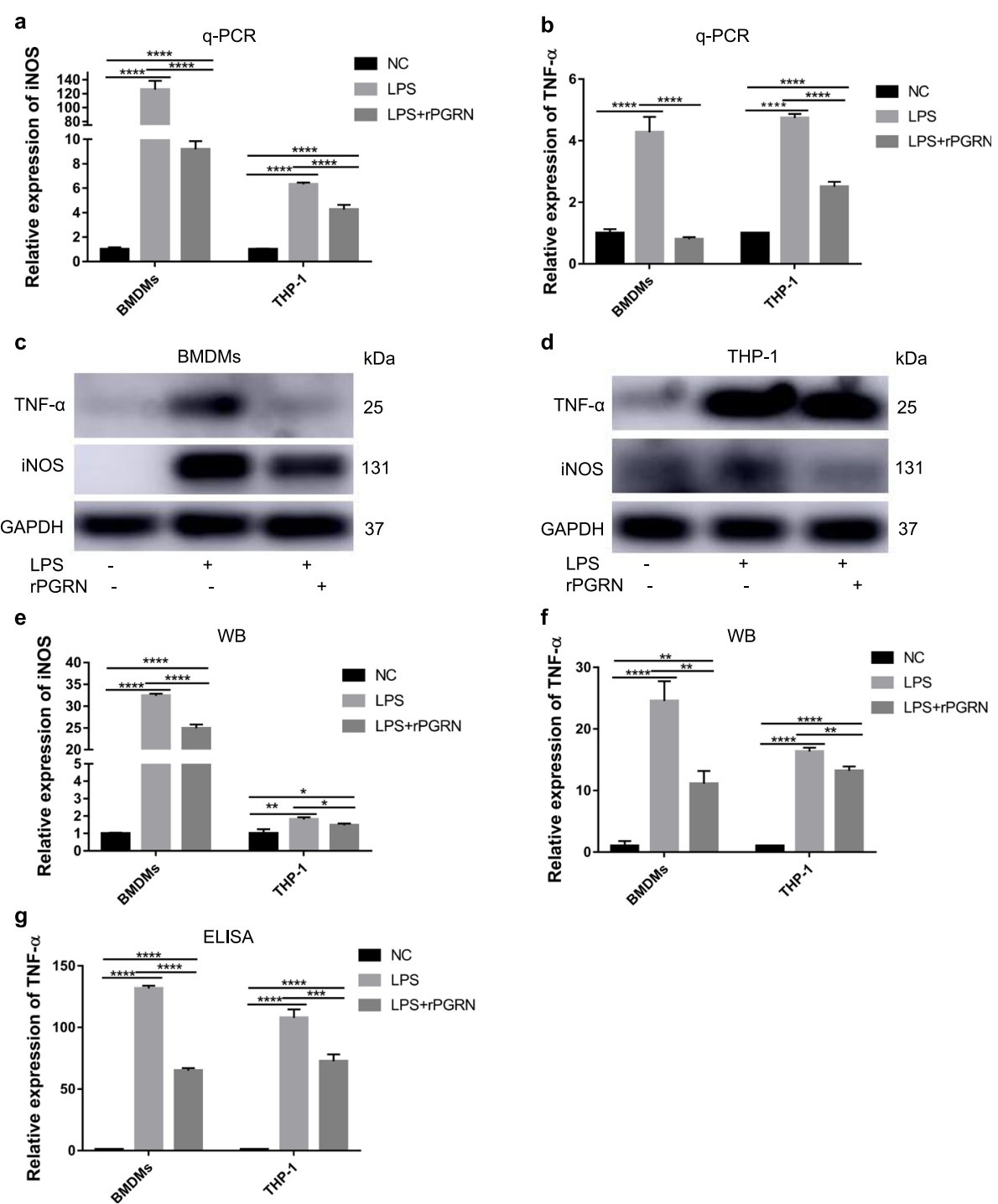

Fig. 7 Inhibitory effects of PGRN on inflammatory cytokines (TNF-a and iNOS) expression in LPS-stimulate BMDMs and THP-1 cells. Cells were treated with LPS with or without $10 \mathrm{ng} / \mathrm{ml} \mathrm{rPGRN}$ for $24 \mathrm{~h}$ and normal medium containing equal amount of PBS to rPGRN and LPS groups was used as negative control. $\mathbf{a}, \mathbf{b}$ iNOS $(\mathbf{a})$ and TNF-a (b) mRNA expressions were determined with q-PCR. $\mathbf{c}-\mathbf{f}$ iNOS $(\mathbf{c}-\mathbf{e})$ and TNF-a $(\mathbf{c}, \mathbf{d}$, $\mathbf{f})$ protein expressions were revealed by Western blot. $\mathbf{g}$ TNF-a secretion was evaluated by ELISA. $N=3, P<0.05(*), P<0.01\left(^{* *}\right), P<0.001\left({ }^{* *}\right)$ or $P$ $<0.0001^{(* * *)}$

surface phenotype marker CD86 expression. More important, anti-TNF- $\alpha$ treatment down-regulated P.g-LPS promoted expression of iNOS and intracellular TNF- $\alpha$. This implies that secondary TNF- $\alpha$ plays an important role in LPS activated M1 polarization. Considering the key role of TNFR1 in PGRN antagonizing the TNF-mediated inflammatory signaling pathway, it is conjectured that PGRN-reversed macrophage M1 polarization challenged by P.g-LPS may be associated with blockage of TNFR1.

Based on its role in up-regulating the expression of proinflammatory genes, NF- $\mathrm{kB}$ pathway has widely been considered as a classical pro-inflammatory signaling pathway [42]. When exposed to stimulus such as LPS or TNF- $\alpha$, inhibitors of p65/p50 heterodimer (IKBs) is phosphorylated and degraded by IKKs, which result in p65/p50 neuclear translocation. Eventually, the transcription of target genes is activated [43]. To explore if NF- $\mathrm{kB}$ pathway is involved in reversing action of PGRN for LPS-promoted M1 polarization, RAW264.7 cells were treated by rPGRN (10 $\mathrm{ng} / \mathrm{ml}$ ) and P.g-LPS with or without rPGRN. Our results verified that presence of $r$ PGRN suppressed activation of NF-кB induced by LPS, decreased phosphorylation of ІкB kinase $(\mathrm{IKK} \alpha / \beta)$, and $\mathrm{IKB} \alpha$, and reduced nuclear translocation of NF- $\mathrm{KB}$ p65 and its phosphorylation. In addition, given that MAPK pathway is also critical pro-inflammatory signaling pathway [44-46] and especially JNK and p38 are 
widely considered motivators of ІкВ $\alpha$ degration, we also examined whether anti-M1 polarization mechanism of PGRN may be associated with MAPK pathway. As shown in Fig. 6, $10 \mathrm{ng} / \mathrm{ml} \mathrm{rPGRN}$ significantly inhibited LPSactivated JNK and p38, though PGRN moderately phosphorylate JNK and p38. These results suggest that NF-KB and MAPK/ JNK/ p38 pathways are involved in reversing action of PGRN for LPS-promoted M1 polarization.

\section{Conclusions}

Our study demonstrates that P.g-LPS stimulates M1 polarization via NF- $\mathrm{kB}$ and MAPK pathways and TNF- $\alpha$ mediates, while PGRN efficiently inhibits this process. However, the mechanism and specific role of TNFRs in PGRN mediated inhibition of M1 polarization remains to be explored. Besides, though we have shown that PGRN protects against experimental periodontitis [30] and promotes inflammatory periodontal bone defect regeneration in rats [31], whether this in vivo efficacy of PGRN is related to anti-M1 polarization waits for investigation.

\section{Methods}

Cell culture and polarization stimulation

RAW264.7 cells were obtained from Stem Cell Bank, Chinese Academy of Sciences. Mouse BMDMs were isolated from femur and tibia of C57BL/6 mice which were purchased from Institute of Shandong University Animal Experimental Center and differentiated into M0 macrophage by $25 \mathrm{ng} / \mathrm{ml}$ recombinant macrophage colony-stimulating factor (M-CSF) (R\&D Systems, Minneapolis, MN, USA) treatment for 4 days. THP-1 cells (Stem Cell Bank, Chinese Academy of Sciences) were differentiated into M0 by 100 ng/ml PMA (Sigma, USA) treatment for $48 \mathrm{~h}$. All cells were cultured in DMEM (Hyclone, Logan, UT, USA) containing $10 \%$ foetal bovine serum (FBS) (BioInd, Kibbutz, Israel) at 37 ${ }^{\circ} \mathrm{C}$ with $5 \% \mathrm{CO}_{2}$. When reached $80 \%$ confluence, cells were scraped, dissociated and counted and then plated in 6-well plates at a concentration of $2 \times 10^{5} / \mathrm{ml}$ (in RAW264.7 cells)

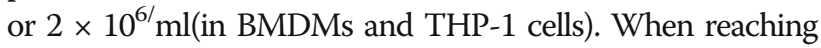
$60 \%$ confluence, cells were stimulated by $100 \mathrm{ng} / \mathrm{ml} \mathrm{P.g-LPS}$ (InvivoGen, San Diego, CA, USA) with or without different doses of rPGRN (Sino Biological, Beijing, China) and TNF- $\alpha$ antibody ( $5 \mu \mathrm{g} / \mathrm{ml}$; Abcam, Cambridge, UK) or a variety of concentrations of rTNF- $\alpha$ (Peprotech, Rocky Hill, NJ, USA) for 24 or $48 \mathrm{~h}$, depending on different experimental goals. The normal medium containing equal amount of PBS to rPGRN and LPS groups was used as negative control.

\section{Flow cytometry}

The surface markers of stimulated cells were detected by flow cytometry. Briefly, RAW264.7 cells were collected from 6-well plates after stimulation for $24 \mathrm{~h}$ and washed three times with PBS. The cell suspension respectively containing $1 \times 10^{6}$ M0-unpolarized or M1-polarized cells was then divided into $1.5 \mathrm{ml} \mathrm{EP}$ tubes and incubated with blocking antibody CD16/32 (Biolegend, San Diego, CA, USA) on ice for $10 \mathrm{~min}$. After washed twice, cells were incubated in PBS plus Intrapore Permeabilization reagent and the following antibodies (PE anti-mouse CD86 and APC anti-mouse CD206 (both from Biolegend)) on ice for $30 \mathrm{~min}$ in the dark. After washed twice, cells was suspended in $500 \mu \mathrm{l} \mathrm{PBS}$ with $3 \% \mathrm{FBS}$ and then detected by flow cytometry (BD Biosciences, San Diego, CA, USA).

\section{Cell proliferation assay}

RAW264.7 cells were counted and seeded in a 96-well plate (3000/well) and cultured in medium plus rPGRN at variable concentrations $(5,10,20,40,80,160,320 \mathrm{ng} / \mathrm{ml})$ or normal medium for 24,48 and $72 \mathrm{~h}$. Then, according to the instruction, the culture medium was replaced by $100 \mu \mathrm{l}$ DMEM medium plus $10 \mu \mathrm{l}$ cck-8 reagent (MCE, Shanghai, China) and the cells were incubated for another $2 \mathrm{~h}$ at $37{ }^{\circ} \mathrm{C}$ in $5 \% \mathrm{CO}_{2}$ incubator. Absorbance at $450 \mathrm{~nm}$ was read by a microplate reader (SPECTRO star Nano) and cell viability was verified by the percent of the absorbance of various concentrations versus control group.

\section{Quantitative real-time PCR}

Real-time reverse transcriptional polymerase chain reaction was performed as follows. Total cellular RNA was isolated from RAW264.7, THP-1 and BMDM cells with TRIzol reagent (Takara, Kusatsu, Japan) and then reverse-transcribed into cDNA with PrimeScript $^{\circ}$ RT reagent kit with gDNA Eraser (Takara) according to the concentration. Afterwards, Real-time PCR was performed with $\mathrm{SYBR}^{\circ}$ Premix Ex Taq II (Takara). Analysis was performed on Light Cycler 96 Real-Time PCR System (Roche, Basel, Switzerland). The housekeeping gene GAPDH was used for normalization. The primers used in this study are shown in Table 1.

\section{Western blot assay}

Cells were lysed with radioimmunoprecipitation assay (RIPA) lysis buffer (Solarbio, Beijing, China) on ice for 30 min and decomposed with ultrasonic. Afterwards, the mixture was centrifugated at $12,000 \mathrm{rpm}$ at $4{ }^{\circ} \mathrm{C}$ for $15 \mathrm{~min}$ to eliminate the dead cell debris. Protein concentration was detected by BCA protein assay kit (KeyGEN BioTECH, Nanjing, China). After denaturation with loading buffer at $100{ }^{\circ} \mathrm{C}, 20 \mu \mathrm{g}$ protein samples were separated in $10 \%$ sodium dodecyl sulfate-polyacrylamide gel electrophoresis (SDS-PAGE) and then transferred to polyvinylidene fluoride (PVDF) membranes (Millipore, Billerica, MA, USA). Membranes were blocked in 5\% milk for $1 \mathrm{~h}$, then covered with the primary antibodies overnight at $4{ }^{\circ} \mathrm{C}$ and incubated with anti-mouse or anti-rabbit secondary antibodies (1:10000; Proteintech, Chicago, IN, USA) for $1 \mathrm{~h}$ at room temperature on shaker. The protein bands were visualized 
Table 1 primer sequences used in this study

\begin{tabular}{llll}
\hline Gene & Full name & Forward $\left(5^{\prime}-3^{\prime}\right)$ & Reverse $\left(5^{\prime}-3^{\prime}\right)$ \\
\hline TNF-a & Tumor necrosis factor-a & GCCTCTTCTCATTCCTGCTTG & GGCCATTTGGGACTTCTCA \\
iNOS & Inducible nitric oxide synthase & TGGAGCCAGTTGTGGTTGTC & GGTCGTAATGTCCAGGAAGTAG \\
PGRN & Progranulin & CCTGGTTCACACACGATGCG & CAGGTGGTCGGAACAGCAGA \\
\hline
\end{tabular}

with chemiluminescent HRP reagents (Millipore, Darmstadt, Germany). Image J 1.44 was used to analyze the protein expression. The primary antibodies were as follows: TNF- $\alpha$ (1:1000; CST, Danvers, MA, USA), iNOS (1:1000; Abcam, Cambridge, UK), Arg-1 (1:500; Santa Cruz, CA, USA), PGRN (1:1000; Abcam), NF-кB p65 (1:1000; CST), phospho-NF-кB p65 (1:1000; CST), ІкB $\alpha$ (1:1000; CST), phospho-IкB $\alpha$ (1:1000; CST), IKK $\alpha$ (1:500; Santa Cruz), rabbit anti-IKK $\beta$ (1:1000; CST), phospho-IKK $\alpha / \beta$ (1:1000; CST), p38 (1:1000; Abcam), phospho-p38 (1:1000; Abcam), JNK (1:1000; Abcam), phospho-JNK (1:1000; Abcam), ERK1/2 (1:1000; Abcam), phospho-ERK1/2 (1:1000; Abcam), GAPDH (1:10000; Proteintech).

\section{Enzyme-linked immunosorbent assay (ELISA)}

Cell supernatant was collected from RAW264.7, THP-1 and BMDM cells, centrifuged at $12,000 \mathrm{rpm}$ at $4{ }^{\circ} \mathrm{C}$ for 10 min and the concentrations of TNF- $\alpha$ and PGRN were measured with ELISA kits (Novus Biologicals, CO, USA or Abcam, Cambridge, UK). All samples were assayed in triplicate and measured at $450 \mathrm{~nm}$ wavelength.

\section{Immunocytochemistry}

RAW264.7 cells plated in 24-wells plate were fixed with $4 \%$ paraformaldehyde for $10 \mathrm{~min}$ in a fume hood, permeabilized using $0.5 \%$ Triton X-100 (Solarbio, Beijing, China) for $10 \mathrm{~min}$ and rinsed three times with cold PBS for $5 \mathrm{~min}$ for each. After being blocked with $5 \%$ goat serum for $1 \mathrm{~h}$, cells were incubated with an anti-NF-kB p65 primary antibody (1:500; CST) overnight at $4{ }^{\circ} \mathrm{C}$. After washed with cold PBS twice, $1 \%$ Tween PBS once and incubated with Alexa Fluor 594conjugated goat anti-rabbit IgG secondary antibody (1: 500; Proteintech) for $1 \mathrm{~h}$ in the dark, nuclei were stained with DAPI (Proteintech). Images were detected with fluorescence microscope (OLYMPUS, Tokyo, Japan).

\section{Statistical analysis}

Experiment results were expressed as the mean \pm SD of at least 3 independent experiments and GraphPad Prism 7 software (San Diego, CA) was used for statistical analysis. Difference between groups was assessed by Unpaired two-tailed Student's $t$-test and one-way ANOVA. Statistical significance was expressed as $P<0.05\left(^{(*)}, P<\right.$ $0.01{ }^{(* * *)}, P<0.001{ }^{(* * *)}$ or $\left.p<0.00011^{(* * * *)}\right)$.

\section{Abbreviations}

PGRN: Progranulin; rPGRN: Recombinant PGRN; LPS: Lipopolysaccharide; IFN$\gamma$ : Interferon gamma; TNF-a: Tumor necrosis factor; iNOS: Inducible nitric oxide synthase; CCK-8: Cell counting kit-8; P.g: Porphyromonas gingivalis; IL1/4/6/8/10//12/13: Interleukin-1/4/6/8/10/12/13; TNFRs: Tumor-necrosis-factor receptors; MMPs: Matrix metalloproteinases; MIP-1a: Macrophage inflammatory protein; rPGRN: Recombinant PGRN; rTNF-a: Recombinant TNFa; anti-TNF-a: Tumor necrosis factor alpha antibody; MAPK: Mitogenactivated protein kinase; q-PCR: Quantitative Real-Time PCR; ELISA: Enzymelinked immunosorbent assay; Fig.: Figure

\section{Acknowledgements}

Not applicable.

\section{Authors' contributions}

PY, CY and LL designed the project. HG and AS supervised the work. LL was responsible for conduction of the experiments. JH, SJ, LZ, SL and YZ collected and analyzed the data. PY and LL interpreted and composed the manuscript. All authors read and approved the final manuscript.

\section{Funding}

The funding was needed to pay the reagents, cell lines and so on and different items of expenditure was supported respectively by the National Natural Science Foundation of China (Grant No. 81771076, 81702684), Beijing, China and the Construction Engineering Special Fund of "Taishan Scholars", Jinan, China. The funders agreed with study proposal but did not take any active part in the design of the study and collection, analysis, and interpretation of data.

\section{Availability of data and materials}

The datasets in the current study are included in the published article or available from the corresponding author on reasonable request.

Ethics approval and consent to participate

The use of mice was approved by Medical Ethics Committee of School of Stomatology, Shandong University (Protocol Number: 201712).

\section{Consent for publication}

Not applicable.

\section{Competing interests}

The authors declare that they have no competing interests.

\section{Author details}

'Department of Periodontology, School of Stomatology, Shandong University, 44 West Wenhua Road, Jinan 250012, Shandong, People's Republic of China. ${ }^{2}$ Shandong Provincial Key Laboratory of Oral Tissue Regeneration, Jinan, Shandong, China. ${ }^{3}$ Shandong Engineering Laboratory for Dental Materials and Oral Tissue Regeneration, Jinan, Shandong, China. ${ }^{4}$ Department of Oral and Maxillofacial Surgery, Qilu Hospital and Institute of Stomatology, Shandong University, Jinan 250012, Shandong, People's Republic of China.

Received: 2 November 2019 Accepted: 20 April 2020

Published online: 05 June 2020

\section{References}

1. Kinane D, Bouchard P. Group EoEWoP: periodontal diseases and health: consensus report of the sixth European workshop on periodontology. J Clin Periodontol. 2008;35(8 Suppl):333-7.

2. Gokhale SR, Padhye AM. Future prospects of systemic host modulatory agents in periodontal therapy. Br Dent J. 2013;214(9):467-71.

3. Azuma MM, Samuel RO, Gomes-Filho JE, Dezan-Junior E, Cintra LT. The role of IL-6 on apical periodontitis: a systematic review. Int Endod J. 2014;47(7): 615-21. 
4. Buduneli N, Kinane DF. Host-derived diagnostic markers related to soft tissue destruction and bone degradation in periodontitis. J Clin Periodontol. 2011;38(Suppl 11):85-105.

5. Kinane DF. Causation and pathogenesis of periodontal disease. Periodontol. 2001;25:8-20.

6. Gordon $\mathrm{S}$. The role of the macrophage in immune regulation. Res Immunol. 1998;149(7-8):685-8.

7. Sima C, Glogauer M. Macrophage subsets and osteoimmunology: tuning of the immunological recognition and effector systems that maintain alveolar bone. Periodontol. 2013;63(1):80-101.

8. Sima C, Viniegra A, Glogauer M. Macrophage immunomodulation in chronic osteolytic diseases-the case of periodontitis. J Leukoc Biol. 2019; 105(3):473-87.

9. Gemmell E, McHugh GB, Grieco DA, Seymour GJ. Costimulatory molecules in human periodontal disease tissues. J Periodontal Res. 2001;36(2):92-100.

10. Yang J, Zhu Y, Duan D, Wang P, Xin Y, Bai L, Liu Y, Xu Y. Enhanced activity of macrophage M1/M2 phenotypes in periodontitis. Arch Oral Biol. 2018;96:234-42.

11. Lam RS, O'Brien-Simpson NM, Lenzo JC, Holden JA, Brammar GC, Walsh KA, McNaughtan JE, Rowler DK, Van Rooijen N, Reynolds EC. Macrophage depletion abates Porphyromonas gingivalis-induced alveolar bone resorption in mice. J Immunol. 2014;193(5):2349-62.

12. Zhou LN, Bi CS, Gao LN, An Y, Chen F, Chen FM. Macrophage polarization in human gingival tissue in response to periodontal disease. Oral Dis. 2019; 25(1):265-73.

13. Holden JA, Attard TJ, Laughton KM, Mansell A, O'Brien-Simpson NM Reynolds EC. Porphyromonas gingivalis lipopolysaccharide weakly activates $\mathrm{M} 1$ and $\mathrm{M} 2$ polarized mouse macrophages but induces inflammatory cytokines. Infect Immun. 2014;82(10):4190-203.

14. Lam RS, O'Brien-Simpson NM, Holden JA, Lenzo JC, Fong SB, Reynolds EC. Unprimed, M1 and M2 macrophages differentially interact with Porphyromonas gingivalis. PLoS One. 2016;11(7):e0158629.

15. He D, Kou X, Luo Q, Yang R, Liu D, Wang X, Song Y, Cao H, Zeng M, Gan Y, et al. Enhanced M1/M2 macrophage ratio promotes orthodontic root resorption. J Dent Res. 2015:94(1):129-39.

16. Bhandari $V$, Palfree RG, Bateman A. Isolation and sequence of the granulin precursor cDNA from human bone marrow reveals tandem cysteine-rich granulin domains. Proc Natl Acad Sci U S A. 1992;89(5):1715-9.

17. Zhu J, Nathan C, Jin W, Sim D, Ashcroft GS, Wahl SM, Lacomis L, ErdjumentBromage $\mathrm{H}$, Tempst $\mathrm{P}$, Wright CD, et al. Conversion of proepithelin to epithelins: roles of SLPI and elastase in host defense and wound repair. Cell. 2002;111(6):867-78.

18. Bateman A, Bennett HP. Granulins: the structure and function of an emerging family of growth factors. J Endocrinol. 1998;158(2):145-51.

19. Arechavaleta-Velasco F, Perez-Juarez CE, Gerton GL, Diaz-Cueto L. Progranulin and its biological effects in cancer. Med Oncol. 2017;34(12):194.

20. Paushter $\mathrm{DH}, \mathrm{Du} \mathrm{H}$, Feng T, Hu F. The lysosomal function of progranulin, a guardian against neurodegeneration. Acta Neuropathol. 2018;136(1):1-17.

21. Zhao YP, Tian QY, Frenkel S, Liu CJ. The promotion of bone healing by progranulin, a downstream molecule of BMP-2, through interacting with TNF/TNFR signaling. Biomaterials. 2013;34(27):6412-21.

22. Qin J, Díaz-Cueto L, Schwarze JE, Takahashi Y, Imai M, Isuzugawa K, Yamamoto S, Chang KT, Gerton GL, Imakawa K. Effects of progranulin on blastocyst hatching and subsequent adhesion and outgrowth in the mouse. Biol Reprod. 2005;73(3):434-42.

23. Tang W, Lu Y, Tian QY, Zhang Y, Guo FJ, Liu GY, Syed NM, Lai Y, Lin EA, Kong L, et al. The growth factor progranulin binds to TNF receptors and is therapeutic against inflammatory arthritis in mice. Science. 2011;332(6028):478-84.

24. Wei F, Zhang Y, Zhao W, Yu X, Liu CJ. Progranulin facilitates conversion and function of regulatory $T$ cells under inflammatory conditions. PLoS One. 2014;9(11):e112110.

25. Wei J, Hettinghouse A, Liu C. The role of progranulin in arthritis. Ann N Y Acad Sci. 2016;1383(1):5-20.

26. Thurner L, Stoger E, Fadle N, Klemm P, Regitz E, Kemele M, Bette B, Held G, Dauer $M$, Lammert $F$, et al. Proinflammatory progranulin antibodies in inflammatory bowel diseases. Dig Dis Sci. 2014;59(8):1733-42.

27. Huang K, Chen A, Zhang X, Song Z, Xu H, Cao J, Yin Y. Progranulin is preferentially expressed in patients with psoriasis vulgaris and protects mice from psoriasis-like skin inflammation. Immunology. 2015;145(2):279-87.

28. Jian J, Li G, Hettinghouse A, Liu C. Progranulin: a key player in autoimmune diseases. Cytokine. 2018;101:48-55.
29. Thurner L, Preuss KD, Fadle N, Regitz E, Klemm P, Zaks M, Kemele M, Hasenfus A, Csernok E, Gross WL, et al. Progranulin antibodies in autoimmune diseases. J Autoimmun. 2013;42:29-38.

30. Li X, Zuo Z, Chen Q, Li J, Tang W, Yang P. Progranulin is highly expressed in patients with chronic periodontitis and protects against experimental periodontitis in rats. J Periodontol. 2018;89(12):1418-27.

31. Chen Q, Cai J, Li X, Song A, Guo H, Sun Q, Yang C, Yang P. Progranulin promotes regeneration of inflammatory periodontal bone defect in rats via anti-inflammation, Osteoclastogenic inhibition, and Osteogenic promotion. Inflammation. 2019;42(1):221-34.

32. Pickford F, Marcus J, Camargo LM, Xiao Q, Graham D, Mo JR, Burkhardt M, Kulkarni V, Crispino J, Hering $\mathrm{H}$, et al. Progranulin is a chemoattractant for microglia and stimulates their endocytic activity. Am J Pathol. 2011;178(1): 284-95.

33. Xaus J, Comalada M, Valledor AF, Lloberas J, López-Soriano F, Argilés JM, Bogdan C, Celada A. LPS induces apoptosis in macrophages mostly through the autocrine production of TNF-alpha. Blood. 2000;95(12):3823-31.

34. Zhu LF, Li L, Wang XQ, Pan L, Mei YM, Fu YW, Xu Y. M1 macrophages regulate TLR4/AP1 via paracrine to promote alveolar bone destruction in periodontitis. Oral Dis. 2019.

35. Mobasheri A, Bay-Jensen AC, van Spil WE, Larkin J, Levesque MC. Osteoarthritis year in review 2016: biomarkers (biochemical markers). Osteoarthr Cartil. 2017;25(2):199-208.

36. Sharma M, Patterson L, Chapman E, Flood PM. Salmeterol, a long-acting beta2-adrenergic receptor agonist, inhibits macrophage activation by lipopolysaccharide from Porphyromonas gingivalis. J Periodontol. 2017; 88(7):681-92.

37. Xuan D, Han Q, Tu Q, Zhang L, Yu L, Murry D, Tu T, Tang Y, Lian JB, Stein GS, et al. Epigenetic modulation in periodontitis: interaction of Adiponectin and JMJD3-IRF4 Axis in macrophages. J Cell Physiol. 2016;231(5):1090-6.

38. Belfield LA, Bennett JH, Abate W, Jackson SK. Exposure to Porphyromonas gingivalis LPS during macrophage polarisation leads to diminished inflammatory cytokine production. Arch Oral Biol. 2017:81:41-7.

39. Garaicoa-Pazmino C, Fretwurst T, Squarize CH, Berglundh T, Giannobile W, Larsson L, Castilho RM. Characterization of macrophage polarization in periodontal disease. J Clin Periodontol. 2019;46(8):830-9.

40. Yoo W, Lee J, Noh KH, Lee S, Jung D, Kabir MH, Park D, Lee C, Kwon KS, Kim $J S$, et al. Progranulin attenuates liver fibrosis by downregulating the inflammatory response. Cell Death Dis. 2019;10(10):758.

41. Kroner A, Greenhalgh AD, Zarruk JG, Passos Dos Santos R, Gaestel M, David S. TNF and increased intracellular iron alter macrophage polarization to a detrimental M1 phenotype in the injured spinal cord. Neuron. 2014;83(5): 1098-116.

42. Lawrence T. The nuclear factor NF-kappaB pathway in inflammation. Cold Spring Harb Perspect Biol. 2009;1(6):a001651

43. Viatour P, Merville MP, Bours V, Chariot A. Phosphorylation of NF-kappaB and IkappaB proteins: implications in cancer and inflammation. Trends Biochem Sci. 2005:30(1):43-52.

44. Jang SI, Kim HJ, Kim YJ, Jeong SI, You YO. Tanshinone IIA inhibits LPSinduced NF-kappaB activation in RAW264.7 cells: possible involvement of the NIK-IKK, ERK1/2, p38 and JNK pathways. Eur J Pharmacol. 2006; $542(1-3): 1-7$.

45. Lee $Y H$, Schiemann WP. Fibromodulin suppresses nuclear factor-kappaB activity by inducing the delayed degradation of IKBA via a JNK-dependent pathway coupled to fibroblast apoptosis. J Biol Chem. 2011;286(8):6414-22.

46. Yeung YT, Aziz F, Guerrero-Castilla A, Arguelles S. Signaling pathways in inflammation and anti-inflammatory therapies. Curr Pharm Des. 2018;24(14): 1449-84.

\section{Publisher's Note}

Springer Nature remains neutral with regard to jurisdictional claims in published maps and institutional affiliations. 